\title{
A tradução como particular experiência de leitura: Triz, de Pedro Süssekind
}

\author{
Translation as a distinct experience of reading: \\ Pedro Süssekind's Triz \\ La traducción como particular experiencia de lectura: \\ Triz, de Pedro Süssekind \\ Maria Célia Martirani
}

\section{Resumo}

Levando em consideração que a leitura - sob a perspectiva hermenêutica de Jauss (1993) - é, acima de tudo, um ato interpretativo, privilegiando, de maneira fulcral, o papel do leitor-receptor da obra literária, o presente estudo visa verificar com que recursos procedimentais o romance brasileiro contemporâneo Triz (2011), de Pedro Süssekind, atualiza essa máxima. Além disso, pretende-se observar como, aqui, dialogam os "efeitos da leitura romanesca" (nos termos propostos por Calabrese, 2009) com o conceito de "pulsão de traduzir" (estabelecido por Ricoeur, 2011), uma vez que o protagonista da obra é um narrador, leitor, estudioso de Literatura Russa, que se dedica à tradução do romance de um autor russo fictício. Sendo um leitor muito particular, de certa forma, anula a si mesmo para eleger uma "morada virtual" no texto, numa espécie de "projeção dirigida" (Gombrich, 2007).

Palavras-chave: leitura, tradução, projeção, Triz, Pedro Süssekind.

\begin{abstract}
Considering that reading - under the hermeneutic perspective of Jauss (1993) - is, above all, an interpretive act, that privileges a central role of the reader, the present study aims at verifying procedural resources in the contemporary novel, Triz (2011), by Pedro Süssekind. In addition, it is intended to observe how the "effects of romanesque reading" (in the terms proposed by Calabrese, 2009) with the "drive to translate" concept (established by Ricoeur, 2011) are discussed in the novel, since the protagonist is a narrator, a reader, and a scholar that is dedicated to the translation of a novel by an invented Russian author. Being a very particular reader, in a way he annuls himself in a sort of "directed projection" (Gombrich, 2007).
\end{abstract}

Keywords: reading, translation, projection, Triz, Pedro Süssekind.

\begin{abstract}
Resumen
La lectura, desde la perspectiva hermenéutica de Jauss (1993), es, sobre todo, un acto interpretativo, privilegiando, de manera fulgurante, el papel del lector-receptor de la obra literaria. El presente estudio busca verificar con qué recursos procedimentales la novela brasileña contemporánea, Triz (2011), de Pedro Süssekind actualiza esa máxima. Además, se pretende observar cómo, aquí, dialogan los "efectos de la lectura novelesca" (como propuesto por Calabrese, 2009) con el concepto de "pulsión de traducir" (establecido por Ricoeur, 2011), una vez que el protagonista de la obra es un narrador, lector, estudioso de la literatura rusa, que se dedica a la traducción de la novela de un autor ruso ficticio. Siendo un lector muy particular, de cierta forma, se anula a sí mismo para elegir una "morada virtual" en el texto, en una especie de "proyección dirigida" (Gombrich, 2007).
\end{abstract}

Palabras clave: lectura, traducción, proyección, Triz, Pedro Süssekind.

\footnotetext{
Doutora em Teoria Literária e Literatura Comparada pela Universidade de São Paulo (USP), São Paulo, SP, Brasil. (Dorcid.org/0000-0002-5388-7915. E-mail: mariacelia.martirani@gmail.com.
} 
Em instigante ensaio intitulado "Wertherfieber, bovarismo e outras patologias da leitura romanesca", o professor e crítico literário italiano Stefano Calabrese (2009) dedica-se a traçar um panorama dos efeitos da leitura de romances na Europa, especialmente a partir da segunda metade do século XVIII. Ao longo desse percurso faz-se necessário notar o quanto o século XIX é o que se destaca como um verdadeiro divisor de águas no que diz respeito às alterações comportamentais dos receptores de obras ficcionais.

A assim chamada "mania de leitura" se favoreceria, então, de aparatos simbólicos, estratégias diegéticas e mudanças do horizonte de expectativa, criados no bojo dos recursos procedimentais de que lançavam mão, em grande parte, os romancistas da época. Tudo colaborava para que se reforçassem modelos de identificação empática do leitor de romances com os mundos ficcionais, em sentido radicalmente oposto ao que se verificava antes. Isso se deu, em boa medida, pela decadência do paradigma trágico, que, como assinala Lessing, provocava um "ato de distanciamento cognitivo da mediocridade do leitor em relação à heroicidade da personagem literária" (Lessing apud Calabrese, 2009, p. 702).

O romance passa a ser então, mais do que tudo, um espaço de identificação possível (homoiosis), que legitima - para o leitor - a ilusão como condição na qual o sujeito se esquece de si mesmo "para adentrar no reino do indistinto, do desdiferenciado" (Calabrese, 2009, p. 703).

Uma das consequências desse processo de identificação é o deslocamento do que Jauss (1993) denomina "horizonte de expectativa interno" ao texto para o "horizonte de expectativa externo" ao texto, ou seja, para o do mundo da vida, onde o receptor pode, até mesmo, inventar uma nova identidade. Daí por que, conforme elucida Albert Thibaudet:

Se o romance sempre existiu, os leitores de romance (precisamente, liseurs) nascem apenas com a modernidade e constituem autênticos viveurs de romans, para os quais a literatura não se dá como um excedente comparativo ou uma adição de experiência, mas como uma despedida de si mesmo ou uma autossubtração (Thibaudet apud Calabrese, 2009, p. 715).

A partir daí, aquilo que acabará se constituindo, no limite, como um "caso patológico" é a exacerbação dessa "ilusão romanesca", quando os leitores passam a incorporar, literalmente, as características das personagens. De certa forma, anulam a si mesmos para eleger uma "morada virtual" no texto, numa espécie de "projeção dirigida", nos termos propostos por Ernst $\mathrm{H}$. Gombrich em Arte e ilusão. Com efeito, para o eminente estudioso, o "conhecimento projetado" substitui a "percepção" (Gombrich apud Calabrese, 2009, p. 722).

O caso literário que aqui se pretende analisar, o romance Triz (2011), de Pedro Süssekind, em boa medida parece atualizar muitas dessas questões, pois toca de perto nos efeitos que as aventuras desastrosas do protagonista de um romance russo causam no espírito do personagem-narrador-leitor, que precisa traduzi-lo para o português. Mais do que uma patologia da literatura romanesca, o que aqui vai se delineando é um caso de patologia da tradução, entendida como leitura particular.

Evidencia-se, na referida obra, a figura do tradutor como o leitor que tem competência em diversos níveis linguísticos e extralinguísticos. A concepção do processo tradutório passou por uma série de propostas conceituais. Assim, conforme ensina o teórico italiano Enrico Arcaini (1992), num primeiro momento, ela enfatizou a noção de código, na premissa da equivalência sintática, proposta por Kade. Um outro modelo seguinte teria colocado em evidência a importância, nas relações entre as línguas, do referente extralinguístico, entendido como mundo externo. Os códigos linguísticos, então, passam a ser entendidos como potencialidade de significado.

Arcaini postula como central a proposta de Bausch, que insiste em dar maior relevância à figura do tradutor. Segundo essa linha de análise, o modelo tradutório deve ser concebido como a combinação de diversas competências - a tradutória, a contextual, a linguística, sempre levando em consideração o papel do leitor:

O assunto de partida é um texto; o tradutor é um leitor particular, que deve compreender e transmitir ao destinatário os efeitos de sentido encontrados e as funções comunicativas expressas. O tradutor analisa o conteúdo semântico-informativo e, levando em conta as características estilísticas, opera escolhas linguísticas, assumindo, desse modo, a dimensão 
de autor, em uma fase que recria o texto. O tradutor tem, portanto, neste modelo, um papel de primeira importância (Arcaini, 1992, p. 19, tradução e grifo nossos).

Com efeito, Murilo Zaitsev Albuquerque, o protagonista de Triz, é um leitor particular, um estudioso de literatura russa, exímio tradutor, que é também viciado em corridas de cavalos. Cumpre observar quão significativas são as seguintes palavras, logo às primeiras páginas do romance, atribuídas a Charles Bukowski, em explícita investida intertextual: "a vida só faz sentido durante as horas de jogo" (Süssekind, 2011, p. 9).

O que, aos poucos, vai se anunciando, ao longo do entrecho narrativo, não é - como, talvez, se pudesse intuir - apenas mais um caso de jogador compulsivo, diante da inevitável derrocada material e moral, frequente em certa linhagem de personagens literários obcecados por jogatinas. Aliás, o próprio narrador nos remete a outros grandes romancistas russos, que tratam da temática do jogo, instaurando, assim, de modo explícito, como um de seus procedimentos narrativos, o diálogo intertextual, que com eles estabelece. É o que se dá com Dostoiévski ( $O$ jogador, 1866) e, principalmente, com o escritor Gustav Traub (e seu romance fictício, A aposta, que teria sido publicado na Rússia em 1914, obra que Murilo deve traduzir).

Além desses, entre os mais modernos, cumpriria lembrar de Verão em Baden-Baden (1981), de Leonid Tsípkin, ou ainda outro, de matriz freudiana, Aurora (1926), do austríaco Arthur Schnitzler, em que o primeiro-tenente Wilhem, devido às suas pulsões obsessivas, perde-se completamente diante da impossibilidade de saldar uma absurda dívida de jogo. Recorrente em todas essas obras encontra-se o desespero fatal dos que se endividam por conta do vício.

O que passa a ser a linha demarcatória entre Murilo e a maior parte desses personagens é o fato de que ele reflete sobre o ato de jogar como indissociável do ato de viver e também do ato de traduzir/ler (porque, ao longo do romance, revela-se tanto jogador quanto tradutor contumaz) e acredita mais no acaso e na intuição do que nas estratégias articuladas para a almejada vitória:

Já eu, que só enxergo nas corridas as imprevisíveis variações do acaso, até ouço as constantes e variáveis das análises estatísticas, acredito nelas, mas no caminho para o guichê de apostas sempre sou assaltado por alguma intuição definitiva e aparentemente infalível. Os números e os nomes se combinam, tomando forma, e finalmente escolho seguir aquela intuição em vez da estatística. Mesmo assim, é preciso admitir meu fracasso na tentativa de imitar Aleksiéi Ivânovitch, de "Um jogador" ou de Nikolai Kolotov, de "A aposta", afinal meu sangue russo talvez seja muito diluído para gestos dramáticos, dívidas acumuladas, derrocadas e riscos exagerados. Gasto um pouco, ponho na conta do divertimento; a alegria de um ou outro acerto, se não paga as perdas, compensa com sobra as apostas erradas... (Süssekind, 2011, p. 9).

Sem dúvida alguma, Murilo presta homenagem à cultura russa (neto de russo, é estudioso e amante da literatura russa, além de seu tradutor). Atualiza, recupera e dialoga com as obras que têm o jogo como assunto dominante. Mas vai bem além disso porque investe no conceito de leveza do acaso e em suas múltiplas variações, em que o que importa é apostar, mais do que ganhar ou perder. Estabelece, assim, uma curiosa aproximação entre as apostas que faz no Jóquei Clube do Rio de Janeiro, local em que costuma ir por ser viciado em corridas de cavalos, e a tradução do livro que está levando a efeito, justamente intitulado $A$ aposta, do autor russo fictício Gustav Traub. Daí por que, tanto nas questões concernentes às corridas no Jóquei, quanto nas que dizem respeito a seus relacionamentos amorosos, ou mesmo nas escolhas tradutórias que precisa fazer, Murilo encarne, de certa forma, o que Schiller postulara em Sobre a educação estética (1795) a respeito do impulso lúdico como elemento necessário ao ato criativo. Tais ideias de Schiller, fundamentadas em Kant, em síntese revelam que é no estado lúdico, "desinteressado" ou "desinteresseiro" (isto é, sem interesse na existência material do objeto) que o homem supera as dilacerações da vida interessada.

E justamente uma das características mais interessantes do livro de Süssekind resida, talvez, nessa investida deliberada no discurso eminentemente estético, já que, como anunciamos antes, "a vida só faz sentido durante as horas de jogo". 
Se a vida é jogo e a natureza lúdica é intrínseca ao humano - conforme ensina Johan Huizinga em Homo ludens (2000) -, o homem deve jogar com a beleza e fruir o que o ato de apostar traz em si, enquanto fuga possível das demandas da realidade. É esse traço lúdico que perpassa todo o romance, para além do vício que, no caso, não faz do protagonista um perdedor aniquilado, mas alguém que vai aprendendo a jogar com as cartas que a vida lhe apresenta.

A conexão entre arte e vida é transfigurada no romance de Süssekind, na medida em que se estabelece uma equivalência entre o jogo/vício pelas corridas de cavalo e o outro jogo em que o narrador/leitor também se vicia: o da tradução.

De fato, mais do que ser o profissional a quem cabe a tarefa de traduzir a obra $A$ aposta de Gustave Traub, em que o médico russo Nikolai Kolotov será vítima das armadilhas do carteado, Murilo se deixa contaminar por ela, dando indícios de que, assumindo as funções de seu métier, revela-se bem mais do que coautor do texto que se propõe a verter para o português. É como se passasse a vivenciá-lo em sua própria história pessoal. No limite, como já se observou anteriormente, a partir do artigo de Stefano Calabrese, está-se diante de um "caso patológico" de leitura, de exacerbação da "ilusão romanesca". O protagonista de Triz, sofrendo, sobremaneira, os efeitos da leitura vertiginosa que se propõe a fazer, incorpora, literalmente, as características do protagonista de A aposta. Reitera-se ainda, aqui, o conceito de "projeção dirigida" nos termos propostos por Ernst H. Gombrich, pois Murilo se anula para eleger uma "morada virtual", e o "conhecimento projetado" substitui a "percepção" (Gombrich apud Calabrese, 2009, p. 722).

Importa notar o quanto essa obra de Pedro Süssekind incita a uma profunda discussão sobre o papel do tradutor enquanto leitor particular, e ainda sobre os limites e o alcance de seu trabalho.

Italo Calvino, em Mondo scritto e mondo non scritto (2002, p. 84), já postulara que "Tradurre è il vero modo di leggere un testo", ou seja, "traduzir é o verdadeiro modo de ler um texto". Murilo radicaliza essa máxima, pois está tão impregnado do que traduz que talvez se pudesse afirmar que, para ele, "traduzir é o verdadeiro modo de vivenciar um texto".

Tratando magistralmente do tema, o filósofo Paul Ricoeur (2011), no ensaio "Desafio e felicidade da tradução", introduz o conceito de "pulsão de traduzir", retomando a obra A prova do estrangeiro de Antoine Berman. Ele nota o quanto as inúmeras dificuldades ligadas à tradução, muitas vezes, tornam-na uma aposta difícil, ou mesmo impossível de se manter:

Essas dificuldades são resumidas de modo preciso no termo "prova", em seu duplo sentido de "provação" e de "exame". Colocar-se à prova, como se diz, de um projeto, de um desejo, mesmo de uma pulsão: a pulsão de traduzir. Para esclarecer essa prova, eu sugiro comparar a "tarefa do tradutor", de que fala Walter Benjamin, com o duplo sentido que Freud dá à palavra "trabalho", quando ele fala em um ensaio do "trabalho da lembrança", e em outro, do "trabalho do luto". Na tradução também se procede a uma certa salvação e a um certo consentimento de perda (Ricoeur, 2011, p. 21-22).

Conforme nos ensina o hermeneuta francês, o texto de Berman nos coloca diante da existência de dois parceiros em relação ao ato de traduzir: o estrangeiro e o leitor (destinatário da obra traduzida). Entre os dois é que se situa o tradutor - que acaba sendo posto à prova "nessa desconfortável situação de mediador". Mas essa situação de desconforto pode ser minimizada se o tradutor renunciar ao ideal da tradução perfeita: "apenas essa renúncia permite viver, como uma deficiência aceita, a impossibilidade de servir a dois mestres: o autor e o leitor" (Ricoeur, 2011, p. 27).

Ricoeur ainda observa que, apenas a partir do que denomina "luto da tradução perfeita", é que é possível chegar à felicidade de traduzir, pois:

a felicidade de traduzir é um ganho quando, ligada à perda do absoluto linguístico, ela aceita a distância entre a adequação e a equivalência, a equivalência sem adequação. Nisso está sua felicidade. Admitindo e assumindo a irredutibilidade do par do próprio e do estrangeiro, o tradutor encontra sua recompensa no reconhecimento do estatuto incontornável da dialogicidade do ato de traduzir como o horizonte razoável do desejo de traduzir. A despeito da agonística que dramatiza a tarefa do tradutor, este pode encontrar sua felicidade no que eu gostaria de chamar de hospitalidade linguística (Ricoeur, 2011, p. 30). 
No livro de Süssekind, a ênfase que se quer dar à influência da obra de Traub no espírito do narrador-leitor é de tal ordem que a composição romanesca, várias vezes, se utiliza do recurso da apropriação (ipsis literis) de trechos inteiros da obra daquele escritor, traduzidos pelo protagonista.

Se pensarmos no tradutor como um leitor exímio e extremamente habilitado, um leitor particular, um mediador capaz de exercer - como ninguém - uma verdadeira "hospitalidade linguística" no sentido ricoeuriano, no limite, o que aqui se apresenta é a instigante questão dos efeitos do texto no espírito de quem o lê e também da "pulsão de traduzir", que acomete Murilo, tanto quanto sua pulsão pelo jogo.

Assim é que teremos, lado a lado, as apostas nas quais o protagonista investe enquanto jogador viciado em corridas de cavalos, e as apostas que vive fazendo enquanto tradutor (posto à "prova", mediando a língua de partida - a do "estrangeiro" - e a língua de chegada, cujo destinatário é o leitor).

Ainda mais relevante, para reiterar a ideia de tradução enquanto "jogo", é o título do romance do escritor russo que está - naquele momento - sendo traduzido pelo protagonista: $A$ aposta. Subjacente ao ato de traduzir, residiria, também, o risco implícito ao ato de jogar.

Importa notar o quanto esse tipo de procedimento enriquece o romance como um todo, porque, por meio do jogo tradutório, Süssekind aponta para outro grande achado da literatura contemporânea, qual seja, o das projeções.

Com efeito, no primeiro capítulo de Triz, tem-se Murilo apostando numa corrida de cavalos no Jóquei Clube do Rio de Janeiro. O segundo capítulo, num corte abrupto, nos desloca para um dos episódios do romance $A$ aposta, em que o médico russo Nikolai Kolotov surge no inverno rigoroso de Paris, onde se exilara. Tratam-se, a priori, de dois universos muito distintos e dissociados.

É extremamente relevante observar que, do ponto de vista estrutural, o romance se constrói, sobretudo, por meio do recurso da "projeção dirigida", consequência irremediável do ato tradutório - nesse contexto, encarado como pulsão de um tipo peculiar e particular de leitura.

$\mathrm{O}$ ato leitor-tradutor, nesse sentido, é um eixo de força que opera em dois níveis. O primeiro, mais evidente, é o intraficcional, num viés metaliterário (já que Murilo é tradutor literário de Traub):

Kolotov cumprimenta o anfitrião, dizendo-lhe que é uma honra jogar numa mesa com banca tão ilustre. Então Fouquet o saúda amavelmente e indica o lugar vago bem ao lado daquele cavalheiro de grandes olhos negros (olhos vulpinos, segundo a definição de Traub que me levou a consultar o dicionário) dirigidos fixamente para as fichas vermelhas que equilibra em seus dedos finos, como se as examinasse (Süssekind, 2011, p. 35).

O segundo nível é o que se estabelece para fora do âmbito estrito do romance, em que a tradução serviria de ponte de intermediação entre o narrador e o leitor (como se o narrador também precisasse "traduzir" - no sentido de "fazer o receptor entender" - a história de Traub), que, se assim não fosse, ficaria sem saber que Murilo e Kolotov são protagonistas de romances distintos, que se tocam e se refletem especularmente, no jogo das projeções.

Em outras palavras, só depois de termos sido apresentados a Murilo e, em seguida, a Kolotov, é que ficamos sabendo que o primeiro é o tradutor do segundo e que se deixa contaminar tanto pelas atribulações e intrigas do médico viciado em "faraó" (espécie de jogo de cartas, comum à época - fins do século XIX, início do XX, na Rússia) que, a todo momento, evoca os parágrafos e situações que traduz do romance para a sua própria experiência, projetando-se neles (como num jogo de espelhos, em que um revela o outro e vice-versa). De certa forma, os níveis tradutórios de leitura se abrem aos níveis projecionais: Traub está para Süssekind, assim como Kolotov para Murilo.

Por meio de um instigante viés metaliterário, o escritor brasileiro contemporâneo Pedro Süssekind trabalha vários níveis de intertextualidade neste seu romance, Triz. De modo explícito, faz vir à luz a obra de um grande escritor russo fictício Gustav Traub, com quem o protagonistanarrador Murilo Zaitsev Albuquerque dialoga. Mas, talvez, seja apenas e tão somente pelo fato de encarnar de modo intenso e um tanto quanto obsessivo (vivenciando uma nítida "pulsão de traduzir", nos termos propostos por Paul Ricoeur) seu papel de tradutor-leitor, lidando com os embates de ser o mediador entre "o estrangeiro e o leitor", submetendo-se à dura "prova do 
estrangeiro" (como assevera Antoine Berman), que ele cresce, ao longo da narrativa, criando todas as complexidades necessárias para que se obtenha uma boa obra de ficção.

Trata-se, assim, de mais um romance contemporâneo que, ficcionalizando o ato de traduzir e de ler, valoriza a difícil mas apaixonante tarefa do tradutor, em que, mais que tudo, apoiado na premissa ricoeuriana da impossibilidade do "absoluto literário", em que se faz necessário aceitar o luto pela perda da tradução perfeita, o protagonista Murilo faz suas apostas, na vida e na arte, plenamente consciente de que, abrindo mão da presunção de fidelidade tradutória, consegue criar o que Paul Ricoeur denomina como "hospitalidade linguística", já que reconhece o "estatuto incontornável da dialogicidade do ato de traduzir como o horizonte razoável do desejo de traduzir" (Ricoeur, 2011, p. 30).

Concluindo, parece ser inevitável observar que o caso literário que aqui se buscou analisar potencializa uma das máximas protagonizadas por Hans Robert Jauss, em seu célebre A literatura como provocação (1993).

De fato, nesse estudo, o eminente discípulo da hermenêutica de Gadamer, enfatiza o fulcral papel do leitor, minimizando, de certa forma, o próprio trabalho do autor e o texto criado, ultrapassando os dogmas marxistas e formalistas, que não privilegiavam o leitor no ato interpretativo, reforçando o conceito de horizonte de expectativas como impulsor da interpretação:

Uma obra não se apresenta nunca, nem mesmo no momento em que aparece, como uma absoluta novidade, num vácuo de informação, predispondo antes o seu público para uma forma bem determinada de recepção, através de informações, sinais mais ou menos manifestos, indícios familiares ou referências implícitas. Ela evoca obras já lidas, coloca o leitor numa determinada situação emocional, cria, logo desde o início, expectativas a respeito "do meio e do fim" da obra que, com o decorrer da leitura, podem ser conservadas ou alteradas, reorientadas ou ainda ironicamente desrespeitadas, segundo determinadas regras de jogo relativamente ao gênero ou ao tipo de texto (Jauss, 1993, p. 66-67).

O romance de Pedro Süssekind, nesse sentido, não deixa de ser, também, uma obra de apologia ao ato interpretativo, uma vez que confere destaque absoluto ao leitor (protagonista, narrador). Um leitor peculiar e particular que, enquanto tradutor, é o que "verdadeiramente lê o texto", sofrendo, inclusive, algumas das consequências inevitáveis decorrentes dos efeitos que esse seu comportamento de leitor acarreta.

Se, nos termos propostos por Ricoeur, Murilo vivencia uma "pulsão", uma vez que o impulso tradutório é o que o move (no bom sentido disso), nos termos de Stefano Calabrese, a imersão exacerbada na leitura faz com que ele possa se alinhar a outros tantos casos de "patologia" da leitura romanesca, anulando o próprio eu para "outrar-se" em Kolotov, de forma a projetar-se nele.

Seja como for, trata-se de um jogo ficcional instigante, em que os níveis de intertextualidade se aliam em prol da memória da literatura, a nos recordar que, enquanto leitores, somos múltiplos e que infinitas vozes, além da nossa própria, nos habitam.

\section{Referências}

ARCAINI, Enrico (1992). Modelli teorici per la traduzione. In: MINISTERO PER I BENI E LE ATTIVITÀ CULTURALI. La traduzione. Roma: Divisione Editoria. (Quaderni di libri e riviste d'Italia, 28).

BERMAN, Antoine (2011). A prova do estrangeiro In: RICOEUR, Paul. Sobre a tradução. Tradução e prefácio de Patrícia Lavelle. Belo Horizonte: Editora UFMG.

CALVINO, Italo (2002). Tradurre è Il vero modo di leggere un testo. In: CALVINO, Italo. Mondo scritto e mondo non scritto. Milano: Mondadori.

CALABRESE, Stefano (2009). Wertherfieber, bovarismo e outras patologias da leitura romanesca. In: MORETTI, Franco (Org.). A cultura do romance. Tradução de Denise Bottmann. São Paulo: Cosac Naify.

HUIZINGA, Johan (2000). Homo ludens. Tradução de João Paulo Monteiro. São Paulo: Perspectiva. 
JAUSS, Hans Robert (1993). A literatura como provocação. Tradução de Teresa Cruz. Lisboa: Veja.

RICOEUR, Paul (2011). Sobre a tradução. Tradução e prefácio de Patrícia Lavelle. Belo Horizonte: Editora UFMG.

RICOEUR, Paul (2011). Desafio e felicidade da tradução. In: RICOEUR, Paul. Sobre a tradução. Tradução e prefácio de Patrícia Lavelle. Belo Horizonte: Editora UFMG, p. 21-31.

SCHILLER, Friedrich (1963). Cartas sobre a educação estética da humanidade. Tradução de R. Schwarz. São Paulo: Herder.

SÜSSEKIND, Pedro (2011). Triz. São Paulo: Editora 34. 